\title{
PROTECTION OF A LANDSCAPE PARK'S AREA IN THE SPATIAL EXTENT OF IMPACT OF THE POZNAN AGGLOMERATION, MIDWESTERN POLAND
}

\author{
BEATA RASZKA, ELIZA KALBARCZYK*
}

Wroclaw University of Environmental and Life Sciences, Faculty of Environmental Engineering and Geodesy, Department of Spatial Management, Grunwaldzka 55 Street, 50-357 Wroclaw, Poland

Adam Mickiewicz University, Faculty of Geographical and Geological Science, Institute of Socio-Economic Geography and Spatial Management, Department of Spatial Econometrics, Dzięgielowa 27 Street, 61-680 Poznan, Poland; e-mail: ekalb@amu.edu.pl

* Author for correspondence

\begin{abstract}
Raszka B., Kalbarczyk E.: Protection of a landscape park's area in the spatial extent of impact of the Poznan agglomeration, midwestern Poland. Ekológia (Bratislava), Vol. 34, No. 3, p. 268-280, 2015.

This paper points out possibilities for limiting anthropic pressure in the Puszcza Zielonka Landscape Park in Poland. Based on the identification and evaluation of the most precious fragments of the environment, it determines the attractiveness of the park perceived as a complex multi-ecosystem. It also identifies the main spatial problems and symptoms of anthropic pressure. The evaluation was conducted through establishing zones with similar environmental value and the determination of hemeroby indicators. The following basic problems were identified: recreational buildings and the development of settlements, cessation of agricultural production, further division of arable land into smaller plots in the buffer zone, combined with a change of land use. The final result of this research is a map of the functional and spatial division of the park, allowing for its protective, biocenotic and scientific functions and possible use for recreation in line with the principles of sustainable development. We ascertained that the strategic objectives and criteria for shaping spatial structures of protected areas should be included in the local spatial policy.
\end{abstract}

Key words: anthropic pressure, functional division, sustainable development, spatial planning.

\section{Introduction}

Puszcza Zielonka Landscape Park ('the Park') near Poznań, the Wielkopolska voivodeship, Poland, is subject to intense anthropic pressure associated with a change in the use of arable land (Łowicki, 2008; Mizgajski et al., 2010). These changes are taking place both in the Park and in the buffer zones, which have become an attractive area for developers and are being covered by new projects that are not connected with the already existing net of settlements. In addition, buildings are very close to the forest or even deep into the forested areas. The buffer zone is ceasing to play a protective role and instead is becoming a location for threats and negative effects on ecosystems protected in the landscape park. 
The aim of this paper is to determine the preservation of the landscape and environment in the Park, and to identify symptoms of anthropic pressure in the buffer zone. The next task is to establish functional and spatial zones with common environmental characteristics and then provide the principles of protection. Moreover, we will indicate permissible economic activities in the area, in harmony with the environmental conditions in the given functionalspatial zone.

\section{Review of the literature}

A landscape park is a Category V protected area (Protected Landscape/Seascape) according to International Union for Conservation of Nature (IUNC) classification (1994). It is a popular form of protection of natural and cultural sites in Central and Eastern Europe (Czech Republic, Poland, Slovakia, Ukraine), as in most other European countries where there are analogous forms of environmental protection, usually assuming the name natural or regional park (France), or national park (UK; Kundrata, Hušková, 2005; Phillips, Partington, 2005; Stockdale, Barker, 2009; Švajda, 2011; Skokanová, Eremiášová, 2013).

A landscape park can be created due to its natural, historical, cultural and landscape values, in order to preserve and promote these values in a sustainable manner. It is therefore an attempt to connect two activities that in most places of the world are difficult to reconcile, that is, maintain the status quo of the area and at the same time promote its development. Despite the obvious difficulties in the pursuit of sustainable development, in many cases this form of protection (i.e., within Category V) seems to be most appropriate (Angeles, 2001; Brown, 2001; Amend et al., 2008; Mallarach, 2008; Dudley, Stolton, 2012).

Difficulties in the proper management of landscape parks result from the need to take into account the unique characteristics of each protected area, as well as the diversity of local conditions and factors affecting development (Ervin, 2003; Brown et al., 2005; Southworth et al., 2006; Skokanová, Eremiášová, 2013). As there is no single pattern of conduct that could be applied in each landscape park, more research is needed in identifying the functioning of local agricultural and ecosystems (Hayes, 2006; Stockdale, Barker, 2009; Mancinelli et al., 2010; Navarro-Cerrillo et al., 2013; Rosa et al., 2013). Another important group of research issues is problems and conflicts, very frequently occurring in the areas and buffer zones of the parks as a consequence of reconciling conservation and economic functions in the same area (DeFries et al., 2010; Hernik et al., 2013).

Identification of existing and potential threats is one of the most frequently undertaken research topics (Verburg et al., 2006; Mcdonald et al., 2009; Lindner et al., 2010; Wyman, Stein, 2010; Salvati et al., 2013). The subject of threats is particularly important in the case of protected areas located within the strong influence of urban areas. In subsequent years, urbanisation pressures will intensify through the decreasing distance between protected and urbanised areas, amongst other issues (Antrop, 2004; Mcdonald et al., 2008, 2009; Hernik et al., 2013). The greatest pressure will be exerted on areas located within a $50 \mathrm{~km}$ radius of cities (Mcdonald et al., 2009). Poznań, one of Poland's largest cities, exhibits processes characteristic of the 'counterurbanisation', that is, depopulation of the city centre, with the more affluent residents moving to suburban areas or rural areas in search of peace and more 
contact with nature (Berry, 1976; Coombes et al., 1989; Fielding, 1982, Brown, Schafft, 2002; Champion, 2005, Löffler, Steinicke, 2006). Such pressures are already visible in the Zielonka Forest - a landscape park situated 3-25 km from Poznań (Mizgajski et al., 2010).

\section{Methods}

Based on a 1:10 000 scale topographic map, the area of the Park was provisionally divided into sectors with similar ecosystems or types of land use. Then, from April 2011 until August 2012, we conducted field studies in these sectors (environmental inventory and the evaluation of anthropic pressure). The level of anthropic pressure was determined by establishing zones with similar levels of hemeroby (Jalas, 1955; Hill et al., 2002; Ziarnek, 2007). The attractiveness of the landscape was determined using a quality evaluation method (Bartkowski, 1974) and assigning various point values to the levels of given characteristics. The basic study area was $250 \mathrm{~m}^{2}$. The following environmental elements were taken into account: forest (surface area of land covered by forest and the forest edge effect), waters (lakes and the lake edge effect), land relief (denivelations and slopes) and the diversity of land use.

The results of bonitation were presented in cartograms. A method of overlaying (Sołowiej, 1992) was used to obtain a synthetic image of the Park's value, associating the presence of infrastructure with the environmental resources and attractiveness of the landscape. Based on the comparison of ortophotomaps from 2006 and 2010, and the inventory of the land, we indicated areas of arable land in the buffer zone that were subject to urbanisation. The following areas were identified: (1) natural and seminatural landscapes (forest, fields, meadows); (2) urbanised field landscapes with scattered buildings; (3) field landscapes with dense buildings. The preliminary assessments were made based on the ortophotomaps and then verified during field studies. Finally, we prepared a map of the functional and spatial division of the Park, taking into account the protective, biocenotic and scientific functions of the Park, and the potential recreational development that would be in line with the principles of sustainable development.

\section{Study area}

The Puszcza Zielonka Landscape Park (Poland) is situated in the central part of the Wielkopolskie voivodeship (Fig. 1), northeast of the city of Poznań, covering about 12,000 ha (Regulation No. 4/05, 2005).

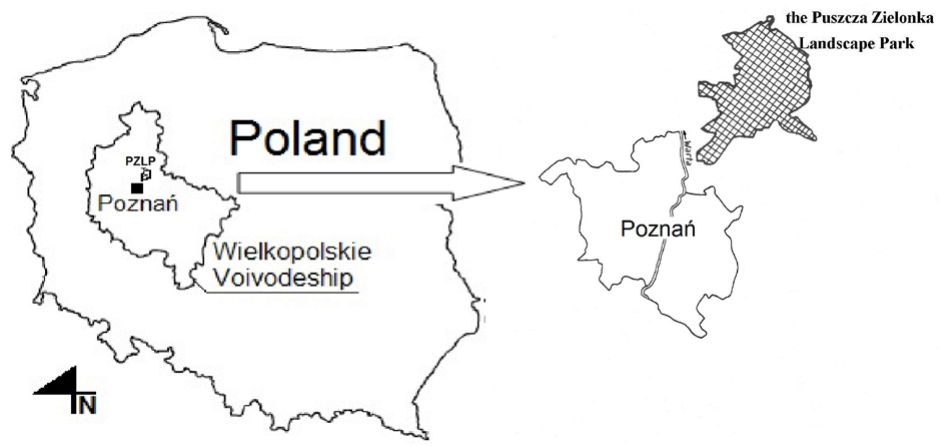

Fig. 1. Location of the Puszcza Zielonka Landscape Park (PZLP, hatched).

Almost $80 \%$ of the Park is covered by forests, including experimental forests $(4,034.43 \mathrm{ha})$ - for example, Douglas spruce and thujas. There are also some precious hydrophilic communities of alder forests, sphagnum birch woods, swamps, wetlands and meadows. The Park includes five natural reserves. A significant part of the Park is covered by a vast outwash high plain with deep post-glacial troughs. The large morphological variability, geological variation of the ground, high variability of soils and flora, all contribute to the high diversity of landscape in the Park. 
The Park is situated in the vicinity of five urban areas - Czerwonak, Murowana Goślina, Pobiedziska, Kiszkowo and Skoki, with the total number of inhabitants near 64,000. The Park includes 22 small settlements (population $<500$ ). The greatest concentrations of population are found in the area of lakes where the buildings are inhabited throughout the year or only seasonally. The areas of the buffer zone are being used for investments associated with the tourist industry (hotels, holiday camps, rehabilitation centres), housing projects and other economic activities.

\section{Results}

The researched area includes numerous unique resources characteristic of different environments (environmental objects, cultural landscape - including archaeological relics, rural architecture, small objects of traditional economy - ponds, millraces and the sites of Catholic worship - e.g., Dąbrówka Kościelna). The diversity of land use is found most distinctly in the buffer zone of the Park, in its southern and southwestern parts (Fig. 2).

Forests are found mainly in the central part of the Park, which is associated with natural reserves and protected forest ecosystems. The most attractive are the areas combining forests and lakes - near the lakes Wronczyńskie, Stęszewskie, Bolechowskie, Leśne and Dzwonowskie. All these water reservoirs occur in afforested areas, but, at the same time, in the vicinity of settled areas. This fact may stimulate the recreational functions of villages near the lakes. However, it also means that preventive actions are necessary to avoid the devastation of the area. On the other hand, these areas, perceived as outer receptive areas, are a barrier to further penetration into the Park.

We identified "the gates of anthropic pressure" (Fig. 3) derived from the following basic spatial problems:

1. Leisure development and growth of settled areas. Recreational buildings are one of the biggest problems in the Puszcza Zielonka Landscape Park, not by their very existence but due to their organisation - 'settled recreation'. Summer houses began to appear within the current limits of the Landscape Park in the 1960s. Currently these are closed residential recreational areas used all year round and located by the lakes. The fundamental mistake in the use of these areas is the very small size of the plots (some with only $200 \mathrm{~m}^{2}$ ) and excessive share of buildings in the total surface area.

In the spatial context, the trend towards agricultural enclaves surrounded by recreational complexes is particularly dangerous. There is also a threat from facilities providing commercial services on

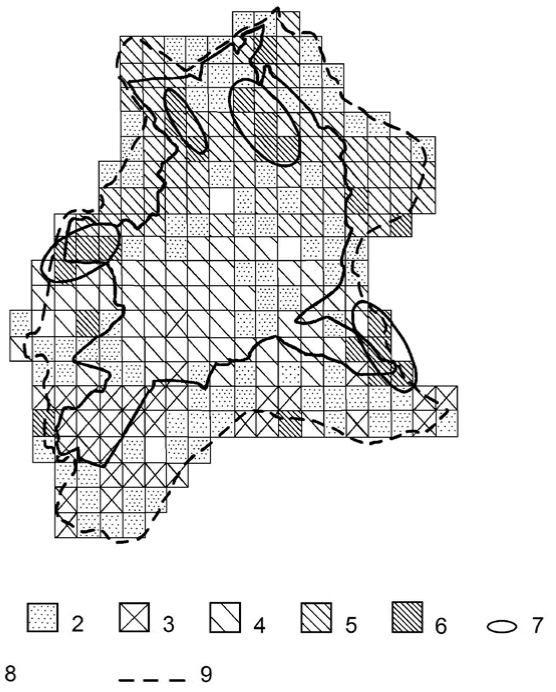

Fig. 2. Landscape and environmental attractiveness of the area - synthesis. Explanations: 1-6 - evaluation of landscape and environment, point values ( 1 - minimum value, 6 - maximum value), increasing; 7 - areas with the highest landscape and environmental value; 8 - the border of the Puszcza Zielonka Landscape Park; 9 - the border of the buffer zone. 


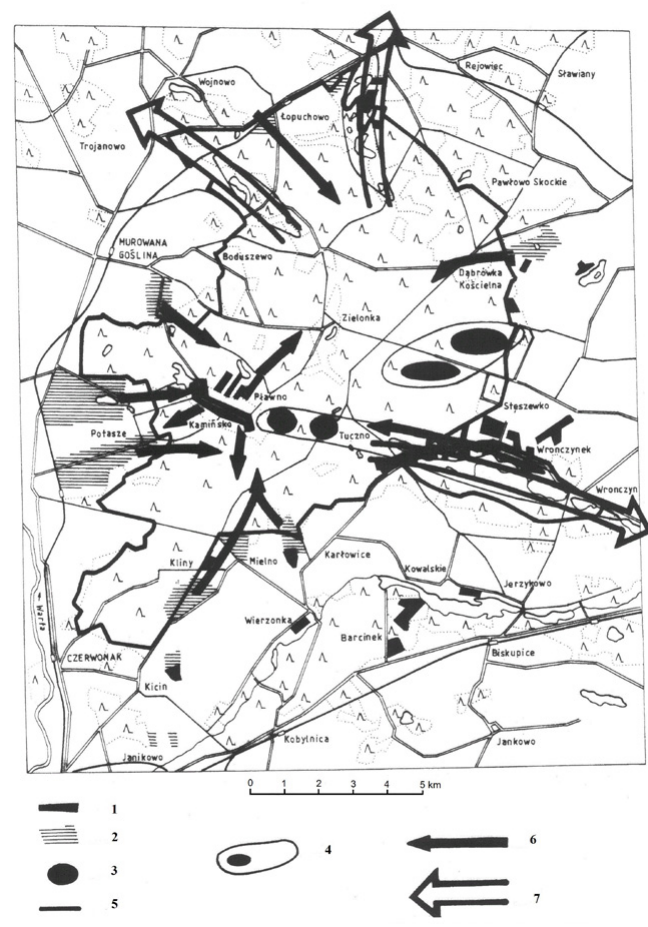

Fig. 3. Identification of the most environmentally precious areas and threatened areas within the boundaries of the Puszcza Zielonka Landscape Park and in the buffer zone. Explanations: 1 - existing buildings; 2 - projected buildings; 3 - natural reserves; 4 - areas with the highest environmental values (reserves, experimental areas, lakes, rivers); 5 - border of the Park; 6 - directions of anthropogenic effects; 7 - ecological connectors.

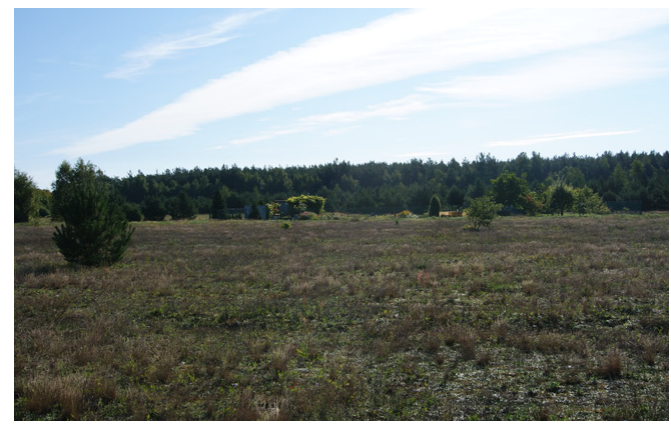

Fig. 4. Natural-seminatural ecotones - the landscape of the buffer zone of the Zielonka Forest Landscape Park subjected to gradual construction of settlements. a large scale, such as hotels, in the centre of the Park. This stands in conflict with the principles of creating zones in protected areas (the principle of minimising external interference and reducing the economic functions from the outside to the inside) and generates a hazard from problems arising from increased traffic and resulting sewage and waste. The summer house estate is located in the buffer zone at the north of the Park, squeezed between the lakes Gackie, Borowie and Księże. This property constitutes a barrier in the natural ecological corridor: the Puszcza Zielonka Landscape Park and the Wągrowiec-Gołańcz Channel Landscape Protection Area.

2. Subdivision (secondary division) of land connected with the change of use in the buffer zone of the Park. Exclusion of land from agricultural production occurs in southern and western parts of the buffer zone. Settlements are built directly in contact with the forest zone, consisting of small plots with a significant percentage of the area covered by buildings. As a result, the Park is increasingly densely surrounded by urban areas located in the buffer zone, which then directly influences the ecosystem of the Park.

The greatest landscape changes have occurred in the buffer zone. In the contact zone between the park and the buffer zone, we distinguished three types of ecotones. For the purpose of this study, we adopted the following nomenclature: (1) natural-seminatural ecotone, occurring between natural and/or seminatural ecosystems (forest/forest, forest/field, field/ field, field/woods; Fig. 4); (2) anthropogenic ecotone in the early stages (a protected area/areas subject to urbanisation and with scattered building; Fig. 5); (3) 
fully developed anthropogenic ecotone (protected area/urban areas with dense buildings; Fig. 6).

It was found that natural ecotones have been preserved near the eastern border of the Park; the biggest transformation has occurred in the south. There and in the west we noted increased urbanisation in the buffer zone and on the border between the buffer zone and the Park (Fig. 7).

Settlements are distant from the existing settlement structure, devoid of municipal infrastructure and probably difficult to integrate with the whole settlement network. Spatial divisions do not respect the fact of liquidity of the field-forest boundary (ecotone zone). Local development plans include small, several square hectare plots, leading to a lack of comprehensive spatial policy and spatial patterns and violating the unity of the functional structures of the environment (e.g., migration routes, scenic panoramas, historical and cultural values), usually because the documents supporting local development plans - such as ecophysiographic studies are of low diagnostic value when prepared for small areas.

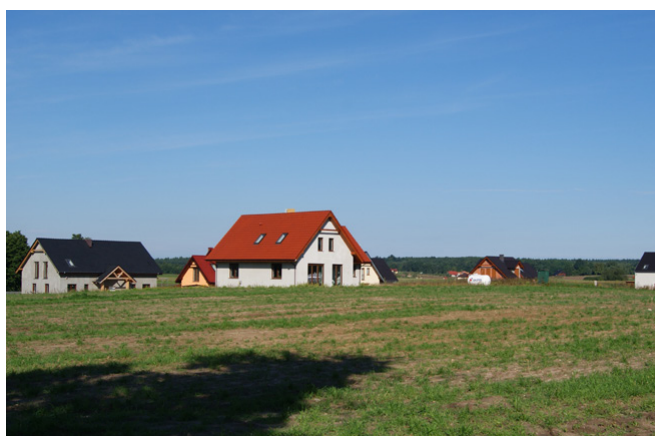

Fig. 5. Anthropogenic ecotones in the early stages - the areas meant for development in the buffer zone of the Zielonka Forest Landscape Park based on the plans of communes.

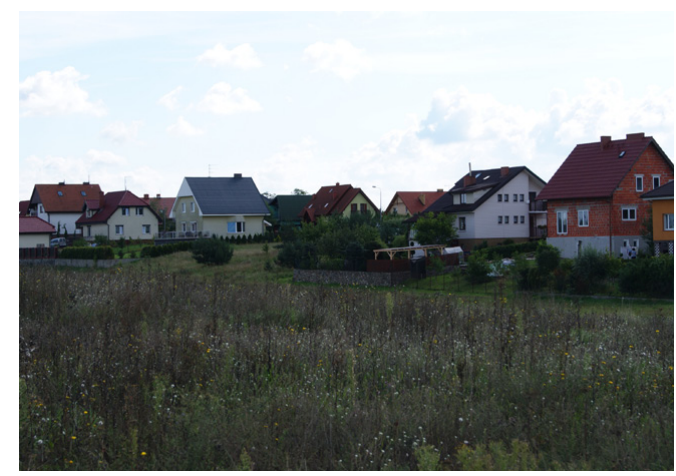

Fig. 6. Fully developed anthropogenic ecotones - new buildings in the buffer zone of the Zielonka Forest Landscape Park, the south-western part.

Emerging residential development often non-critically imitates urban housing patterns, without considering the local nature of buildings and the landscape (a violation of the principle of orderly development and preservation of cultural values). The result is the destruction of the old settlement structures, valuable not only for their aesthetics but the harmonious organisation of space and a clear specific character in settlements near the forest and in rural areas.

\section{Proposals of rationalisation of spatial management in the Puszcza Zielonka Landscape Park}

The analyses enabled the mapping of the functional and spatial distribution of the Park, including security features, scientific biocenotic Park and recreation development opportunities, according to the principles of sustainable development (Fig. 7).

1. Optimisation of the interior of the Park. The park should be a separate functional landscape area, to which indicated use must be formulated (Fig. 7, Table 1). 

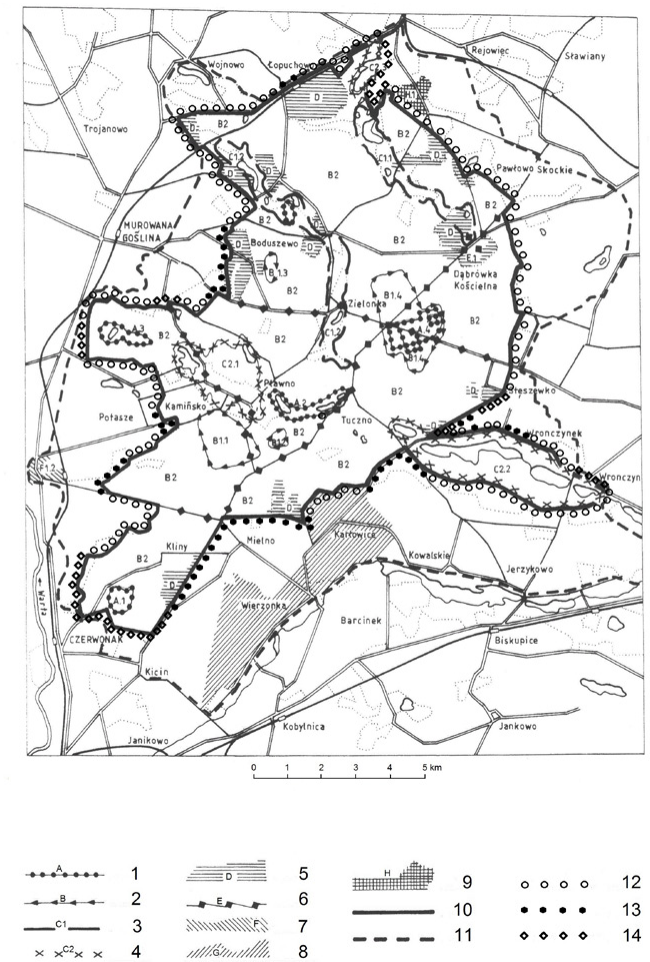

Fig. 7. Functional and spatial division of the Puszcza Zielonka Landscape Park. Explanations: 1 - reserve protection; 2 - protection of the forest ecosystem; 3 - protection of surface water natural landscape; 4 - zone of the extensive recreational use of waters; 5 - protection of non-forested areas; 6 - protection of the cultural landscape; 7 - protection of the cultural-agricultural landscape; 8 - protection of ecological connectors (area of the protected landscape); 9 - areas of intense anthropogenic transformations; 10 - the border of the Puszcza Zielonka Landscape Park; 11 - the border of the buffer zone; 12 - natural-seminatural ecotone; 13 - anthropogenic ecotone in the early stage; 14 - complete anthropogenic ecotone.
Similarly actions should be taken for the buffer zone, where the use of economic development must be defined (Table 2).

2. Redrawing of the boundaries. The Puszcza Zielonka Landscape Park is currently not linked to other areas of the EECONET (ECONET-PL) network. The Park is not spatially connected with other forms of environmental protection in the Wielkopolskie Province, that is, with the River Wełna Valley and GołańczWągrowiec Channel (Dolina Wełny, Rynna Gołaniecko-Wągrowiecka) Landscape Protection Area, the Puszcza Notecka Landscape Protection Area in the north, with the Wielkopolska National Park, the Rogalin Landscape Park and the Landscape Protection Area of the catchment of Kórnik-Zaniemyśl Lakes in the south, the Lednica Landscape Park and the Promno Landscape Park in the east and the Biedrusko Landscape Protection Area in the west. At present, it constitutes a relatively well isolated 'environmental island' in the region (MacArthur, Wilson, 2001). Therefore, it is necessary to show and ensure stable spatial connectors between the different forms of environmental protection in the Warta valley. These stable spatial connectors would have the character of indirect connectors (Fig. 7). Such areas should not be subject to building development, but should preserve their

agricultural use. The connection is possible through the channel of the River Dzwonówka (the northern arm, to the River Wełna Valley and Gołańcz-Wągrowiec Channel Landscape Protection Area), through the channel of Stęszew-Kołatkowo Lakes (the eastern arm, to the Promno Landscape Park) and through the valley of the River Trojanka to the Warta (northwest). These actions will enable the creation of environmentally active space, eliminating the present isolation of the Puszcza Zielonka Landscape Park. Such a space will make possible the preservation of areas of special landscape values in the buffer zone (unique surface features, valleys of watercourses). At present, due to considerable pressure, these areas in the buffer zone are being developed. 
$\mathrm{T}$ a b l e 1. Selected proposal for the management of the Puszcza Zielonka Landscape Park (A-E zones denote the area of the park).

\begin{tabular}{|c|c|c|}
\hline No. & Tasks (zone A) & Implementation \\
\hline & Prepare management plans for reserves & $\begin{array}{l}\text { Request to the Regional Conservator for the pri- } \\
\text { oritisation of preparation of management plans for } \\
\text { reserves located within the Puszcza Zielonka Land- } \\
\text { scape Park }\end{array}$ \\
\hline & $\begin{array}{l}\text { Within zone A, introduce extensive forest manage- } \\
\text { ment limited to sanitation, pruning and thinning }\end{array}$ & Include in forest management plans \\
\hline \multirow[t]{8}{*}{ No. } & Tasks (zone B1) & Implementation \\
\hline & $\begin{array}{l}\text { Do not change the use of forest land to another type } \\
\text { of use }\end{array}$ & Include in forest management plans \\
\hline & Exclude geographically alien species from planting & Include in forest management plans \\
\hline & Prevent the overgrowth of inner forest clearings & $\begin{array}{l}\text { Counteract the natural succession of trees and } \\
\text { shrubs by trimming }\end{array}$ \\
\hline & $\begin{array}{l}\text { Prohibit the establishment of new tourist routes and } \\
\text { the location of tourist facilities, apart from informa- } \\
\text { tion boards }\end{array}$ & Include in forest management plans \\
\hline & Locate educational paths on the edges of the zone & Take into account when creating new pathways \\
\hline & Strive to reduce mass tourist traffic in the area & $\begin{array}{l}\text { Create new opportunities to stay in the park outside } \\
\text { the B1 zone }\end{array}$ \\
\hline & $\begin{array}{l}\text { Restrict traffic on private roads because of the mi- } \\
\text { gration routes of animals }\end{array}$ & $\begin{array}{l}\text { Install message boards (such as 'seasonal ban on en- } \\
\text { try of motor vehicles, does not apply to the Admin- } \\
\text { istration of National Forests') }\end{array}$ \\
\hline \multirow[t]{8}{*}{ No. } & Tasks (zone C1) & Implementation \\
\hline & Exclude lakes from recreational use & $\begin{array}{l}\text { Include in local land use plans and forest manage- } \\
\text { ment plans }\end{array}$ \\
\hline & $\begin{array}{l}\text { Do not build in river valleys - with the exception of } \\
\text { the existing buildings in Głęboczek }\end{array}$ & $\begin{array}{l}\text { Include in local land use plans and forest manage- } \\
\text { ment plans - over } 1 \text { year of consultation with the } \\
\text { inhabitants of Głęboczek regarding the principles } \\
\text { and directions of economic activity }\end{array}$ \\
\hline & Maintain grasslands in the prior use scheme & $\begin{array}{l}\text { Include in local land use plans as ecological corri- } \\
\text { dors and in forest management plans }\end{array}$ \\
\hline & Do not locate large reservoirs in the zone & Include in local land use plans \\
\hline & Prohibit changes in hydrographic conditions & $\begin{array}{l}\text { Include in local land use plans or zoning decision in } \\
\text { the absence of local land use plans }\end{array}$ \\
\hline & $\begin{array}{l}\text { Prohibit fishing on part of the lake bordering the } \\
\text { Forest Reserve 'Żywiec Dziesięciolisty'. Fishing al- } \\
\text { lowed only from fixed platforms with locations } \\
\text { agreed by landscape park authorities }\end{array}$ & Include in forest management plans \\
\hline & Organise the management of water and waste water & $\begin{array}{l}\text { Construction of sewage by local authorities (local } \\
\text { authority association 'Puszcza Zielonka') }\end{array}$ \\
\hline No. & Tasks (zone C2) & Implementation \\
\hline 1. & Provide the lakes for recreational use & $\begin{array}{l}\text { Include in local land use plans and forest manage- } \\
\text { ment plans }\end{array}$ \\
\hline 2. & $\begin{array}{l}\text { Build the necessary recreation infrastructure in } \\
\text { designated public waters, protecting the natural en- } \\
\text { vironment from degradation (e.g., bridges, toilets, } \\
\text { waste containers, parking) }\end{array}$ & Include in local communal budgets \\
\hline
\end{tabular}


T a b l e 1. Selected proposal for the management of the Puszcza Zielonka Landscape Park (A-E zones denote the area of the park) - continued.

\begin{tabular}{|c|c|c|}
\hline 3. & $\begin{array}{l}\text { Take steps to ensure free access to the shores of lakes } \\
\text { in accordance with the Water Law (Journal of Laws } \\
2001 \text {, No. 115, item In } 1229 \text { of } 11 \text { October 2001) }\end{array}$ & $\begin{array}{l}\text { Law enforcement by local governments, forest } \\
\text { guards and fishing guards }\end{array}$ \\
\hline 4. & Organise the management of water and waste water & $\begin{array}{l}\text { Construction of sewage systems by local authorities } \\
\text { (local authority association 'Puszcza Zielonka') }\end{array}$ \\
\hline 5. & $\begin{array}{l}\text { Do not establish new land plots and buildings in the } \\
\text { villages Okoniec, Kamińsko, Pławno, Tuczno and } \\
\text { Stęszewsko }\end{array}$ & $\begin{array}{l}\text { Take into account when drafting local development } \\
\text { plans }\end{array}$ \\
\hline 6. & $\begin{array}{l}\text { Do not establish new recreation and construction plots } \\
\text { in a belt } 100 \mathrm{~m} \text { from the shoreline of surface waters }\end{array}$ & Include in local land use plans \\
\hline No. & $\begin{array}{l}\text { Tasks (zone D - protection of the cultural land- } \\
\text { scape) }\end{array}$ & Implementation \\
\hline 1. & Keep land quality classes I-IV in agricultural use & Include in local land use plans \\
\hline 2. & $\begin{array}{l}\text { Other agricultural land should be left in current use, } \\
\text { with the possibility of afforestation of classes V-VI } \\
\text { (after prior consultation with the institutions in ac- } \\
\text { cordance with applicable law) }\end{array}$ & Include in local land use plans \\
\hline 3. & $\begin{array}{l}\text { Areas designated for buildings should have plots } \\
\text { with average minimum size } 2500 \mathrm{~m}^{2} \text { (with mini- } \\
\text { mum of a given plot at } 1500 \mathrm{~m}^{2} \text { ) }\end{array}$ & Include in local land use plans \\
\hline 4. & Do not designate new areas for development & Take into account when drafting local development plans \\
\hline No. & Tasks (zone E) & Implementation \\
\hline 1. & $\begin{array}{l}\text { Perform a study on the rural landscape of Dąbrówka } \\
\text { Kościelna (indicating the principles of harmonising } \\
\text { contemporary spaces with historical cultural values) }\end{array}$ & $\begin{array}{l}\text { Include in the preparation of local development } \\
\text { plans }\end{array}$ \\
\hline 2. & $\begin{array}{l}\text { Determine the area of conservation protection in } \\
\text { Dąbrówka Kościelna }\end{array}$ & $\begin{array}{l}\text { Prepare a proposal to designate a conservation pro- } \\
\text { tection area }\end{array}$ \\
\hline 3. & $\begin{array}{l}\text { Locate possible housing development in Dąbrówka } \\
\text { Kościelna south of the main road }\end{array}$ & Include in local land use plans \\
\hline No. & $\begin{array}{l}\text { Tasks (zone F - protection of the cultural land- } \\
\text { scape connected with agriculture) }\end{array}$ & Implementation \\
\hline 1. & Determine the area of conservation protection & $\begin{array}{l}\text { Prepare a proposal to designate a conservation pro- } \\
\text { tection area }\end{array}$ \\
\hline 2. & $\begin{array}{l}\text { Newly established buildings should be arranged in } \\
\text { harmony with existing buildings in the village and } \\
\text { the spatial layout (e.g., preserve the form of a unilat- } \\
\text { eral street, oval-shaped village, etc.) }\end{array}$ & $\begin{array}{l}\text { Include in the preparation of local development } \\
\text { plans }\end{array}$ \\
\hline 3. & $\begin{array}{l}\text { Harmonise buildings with the surrounding nature } \\
\text { and landscape; refer to traditional construction in } \\
\text { Wielkopolska. It would be advisable for local devel- } \\
\text { opment plans to be preceded by landscape studies }\end{array}$ & $\begin{array}{l}\text { Include in the preparation of local development } \\
\text { plans }\end{array}$ \\
\hline 4. & $\begin{array}{l}\text { Areas designated for buildings should have plots } \\
\text { with average minimum size } 2500 \mathrm{~m}^{2} \text { (with mini- } \\
\text { mum of a given plot at } 1500 \mathrm{~m}^{2} \text { ) }\end{array}$ & $\begin{array}{l}\text { Include in the preparation of local development } \\
\text { plans }\end{array}$ \\
\hline 5. & $\begin{array}{l}\text { It is recommended moving the fencing of buildings } \\
\text { on newly appointed building plots to at least } 10 \mathrm{~m} \\
\text { from the forest, and building lines should be set at a } \\
\text { distance of at least } 50 \mathrm{~m} \text { from the forest }\end{array}$ & $\begin{array}{l}\text { Include in the preparation of local development } \\
\text { plans }\end{array}$ \\
\hline
\end{tabular}


T a b l e 2. Selected examples of land management agreements of the Puszcza Zielonka Landscape Park (zones F, $\mathrm{G}, \mathrm{H}$ - buffer zone).

\begin{tabular}{|l|l|}
\hline Tasks & Zone \\
\hline Using ecological fuels for heating houses & B2, C1, C2, D, E, F1, F2, G, H \\
\hline $\begin{array}{l}\text { Prohibition of the location of buildings, technical infrastructure and fencing } \\
\text { in a strip } 10 \mathrm{~m} \text { from the edge of the forest in new areas designated for deve- } \\
\text { lopment }\end{array}$ & B2, C1, C2, D, E, F1, F2 \\
\hline $\begin{array}{l}\text { Determine the building line at a distance of at least } 50 \mathrm{~m} \text { from the forest, in } \\
\text { the new areas designated for development }\end{array}$ & B2, C1, C2, D, E, F1, F2 \\
\hline $\begin{array}{l}\text { Areas designated for buildings should have plots with average minimum size } \\
\text { of } 2500 \mathrm{~m} 2 \text { (with minimum of a given plot at } 1500 \mathrm{~m} 2)\end{array}$ & B2, C1, C2, D, E, F1 \\
\hline $\begin{array}{l}\text { Perform a landscape study in drafting local land use plans for new areas de- } \\
\text { signated for development }\end{array}$ & B2, C1, C2, D, E \\
\hline $\begin{array}{l}\text { Prohibition of secondary division of plots within already existing recrea- } \\
\text { tional plots, excluding secondary divisions necessary for technical infra- } \\
\text { structure and roads }\end{array}$ & B2, C1, C2, D, E \\
\hline $\begin{array}{l}\text { Maintain a minimum of } 60 \% \text { of biological activity in areas designated for } \\
\text { buildings, and in recreational plots - a minimum of 70\% }\end{array}$ & B2, C1, C2, D, E \\
\hline Use of architectural forms harmonised with the surrounding landscape park & B2, C1, C2, D, E \\
\hline Prohibition of fences higher than $1.80 \mathrm{~m}$ & B2, C1, C2, D, E \\
\hline $\begin{array}{l}\text { Prohibit the use of fencing in the form of solid walls and those using precast } \\
\text { concrete }\end{array}$ & B2, C1, C2, D, E \\
\hline $\begin{array}{l}\text { Issuance of building permits only to those parcels designated for construc- } \\
\text { tion and recreation, which have full water and waste-water infrastructure }\end{array}$ & B2, C1, C2, D, E \\
\hline
\end{tabular}

3. Protection of the buffer zone against chaotic development. In the area of the buffer zone it is necessary to define the rigors of urban planning and architecture (size of plots, type of building) that would allow preservation of the historically shaped settlement structure and forms of local architecture (historical spatial systems in villages, the principles of location and land development, preservation of the main cultural and landscape characteristics). Consideration for the tradition in shaping the cultural landscape and the addressing historical and regional solutions are meant to counteract the unplanned and chaotic parcelling of land, degradation of the cultural landscape through the inconsiderate location of buildings, particularly temporary buildings: service pavilions, huts, bungalows, unsightly objects of technical infrastructure and aggressive forms of advertising. It is necessary to maintain both the agricultural nature of the buffer zone and harmonious landscape. A park management plan should include a landscape study (with the principles of harmonising buildings with the landscape and protection of historic cultural values). For the preservation of the buffer zone fragments that are of particular landscape value, it is possible to include them as areas of protected landscape.

\section{Discussion}

The area of the Puszcza Zielonka Landscape Park is officially listed as one of the ten most attractive Wielkopolska areas in terms of natural and anthropogenic assets (Spatial Development Plan of the Wielkopolska Province, 2010; Resolution..., 2010. Functions other than 
biocenotic and protective (i.e., economic, housing, recreational and tourist) must only be carried out without breaching the protection of natural resources earmarked for landscape parks and the principles of sustainable development (Brown et al., 2005; Amend et al., 2008; Stockdale, Barker, 2009; Dudley, Stolton, 2012). Hence the need to maintain the ban on the location of investments that result in environmental degradation and change the valuable landscape.

Using the space of landscape parks, which amounts to the creation of concentrated residential lots and holiday buildings, results in a number of threats (Dabrowska-Prot, 1995; Mcdonald et al., 2009; Stockdale, Barker, 2009; Hernik et al., 2013). In the case of the Puszcza Zielonka Landscape Park, this process usually takes place through the change of land status, that is, exclusion from agricultural production. This process is random or purely at the demand of the investor, although it should be preceded by analyses of ecological value. This environmentally and culturally attractive area has been subject to chaotic land development even prior to the establishment of the Park. However, the change of legal status generally did not improve the sustainability of the local land use, which is constantly endangering ecosystems (Kasprzak, Raszka, 2006). Similar processes were observed in the Warsaw metropolitan area (Solon, 2009), during 1950-1990.

Conversion of the agricultural status of land is usually motivated by social needs and the financial benefits obtained by urban areas through higher tax revenues (Wolski et al., 2000; DeFries et al., 2010; Hernik et al., 2013). However, the changes concern mainly the most attractive (in terms of landscape) and most environmentally valuable areas near lakes and forests, which are also the most susceptible to degradation. Changes in the environmental health (deterioration of water quality), depletion of the environment (increase in areas devoid of vegetation, erosion, disappearance of reed beds, 'wild' paths, destruction of undergrowth and trees) and the irreversible transformation of the landscape by non-aesthetic architecture, excessive construction on the surface of land without introducing tall greenery - are only some of the effects of reckless land use (Phillips, 2001; Mcdonald et al., 2008; Stockdale, Barker, 2009; DeFries et al., 2010). Land is often covered by settlements that are structurally urban, but functionally inefficient and without the necessary technical facilities (sanitation, roads, waste management). They also lead to conflicts related to the lack of commonly available beaches and parking spaces. Conflicts that arise in landscape park areas are usually the result of a conflict of interests between the requirements of nature conservation and the inhabitants and local authorities (socio-economic needs; DeFries et al., 2010). Ultimately, the sphere of conflict boils down to the rules of spatial management.

It is necessary to maintain the fragile balance between the natural environment, susceptible to aggressive exploitation, social expectations (including the desire for quick profit), and actually introduced infrastructure (Forman, 1995). The strategic objectives and criteria for spatial management in protected areas, showing the principles and direction of geographical space management, should then be included in the urban spatial policy and local development plans, that is, executive documents (Wolski et al., 2000). This process should be supported through research and expert reports, allowing for the formulation of plans and a comprehensive policy meant to support rural development and minimise any adverse effects (Raszka, 2002).

\section{References}

Amend, T., Brown, J., Kothari, A., Phillips, A. \& Stolton S. (Eds.) (2008). Protected landscapes and agrobiodiversity values. Vol. 1. Values of protected landscapes and seascapes. Heidelberg: Kasparek Verlag. 
Angeles, M.T. (2001). A Peruvian perspective on protected landscapes as a tool for highlands conservation and stewardship. Landscape conservation. Vermont: Conservation Study Institute, IUCN, Woodstock.

Antrop, M. (2004). Landscape change and the urbanization process in Europe. Landsc. Urban Plann., 67, 9-26. DOI: 10.1016/S0169-2046(03)00026-4.

Bartkowski, T. (1974). Applications of physical geography (in Polih). Warszawa-Poznań: PWN.

Berry, B.J.L. (1976). Urbanization and counterurbanization. Beverly Hills, London, Urban Affairs Annual Reviews 11, Sage Publications.

Brown, J. (2001). Stewardship of Andean landscapes: a potential role for category V protected areas. In Landscape conservation (pp. 35-37). Vermont: Conservation Study Institute.

Brown, D.L. \& Schafft K.A. (2002). Population deconcentration in Hungary during the post-socialist transformation. Journal of Rural Studies, 18, 233-244. DOI: 10.1016/S0743-0167(01)00046-8.

Brown, J., Mitchell, N. \& Beresford M. (Eds.) (2005). The protected landscape approach: Linking nature, culture and community. Cambridge: IUCN.

Champion, T. (2005). The counterurbanisation cascade in England and Wales since 1991: the evidence of a new migration dataset. Belgeo, 1-2, 85-101.

Coombes, M., Dalla Longa, R. \& Raybould S. (1989). Counterurbanisation in Britain and Italy: a comparative critique of the concept, causation and evidence. Oxford: Pergamon.

Dabrowska-Prot, E. (1995). Ecological importance of ecotones between forests and crop fields - a synthesis. Ekol. Pol., 43, 135-144.

DeFries, R., Karanth, K.K. \& Pareeth S. (2010). Interactions between protected areas and their surroundings in humandominated tropical landscapes. Biol. Conserv., 143, 2870-2880. DOI: 10.1016/j.biocon.2010.02.010.

Dudley, N. \& Stolton S. (Eds.) (2012). Protected landscapes and wild biodiversity. Vol. 3. Values of protected landscapes and seascapes. Gland: IUCN.

Ervin, J. (2003). Rapid assessment of protected area management effectiveness in four countries. Bioscience, 53, 833841. DOI: 10.1641/0006-3568(2003)053[0833:RAOPAM]2.0.CO;2.

Fielding, A.J. (1982). Counterurbanisation in Western Europe. Progress in Planning, 17(1), 3-52. DOI: 10.1016/03059006(82)90006-X.

Forman, R.T.T. (1995). Land mosaics. The ecology of landscapes and regions. Cambridge: Cambridge University Press.

Hayes, T.M. (2006). Parks, people and forest protection: an institutional assessment of the effectiveness of protected areas. World Development, 34(12), 2064-2075. DOI: 10.1016/j.worlddev.2006.03.002.

Hernik, J., Gawroński, K. \& Dixon-Gough R. (2013). Social and economic conflicts between cultural landscapes and rural communities in the English and Polish systems. Land Use Policy, 30, 800-813. DOI: 10.1016/j.landusepol.2012.06.006.

Hill, M.O., Roy, D.B. \& Thompson K. (2002). Hemeroby, urbanity and ruderality: bioindicators of disturbance and human impact. J. Appl. Ecol., 39(5), 708-720. DOI: 10.1046/j.1365-2664.2002.00746.x.

IUCN (1994). Guidelines for protected area management categories. Gland: IUCN.

Jalas, J. (1955). Hemerobe und hemerochoer Pflanzenarten. Ein terminologoscher Reformversuch. Acta Societatia Pro Fauna et Flora Fennica, 72(11), 1-15.

Kasprzak, K. \& Raszka B. (2006). Protection of area the Zielonka Forest Landscape Park (in Polish). Ekonomia $i$ Środowisko, 2(30), 140-164.

Kundrata, M. \& Hušková B. (2005). Sustaining rural landscapes and building civil society: experience from Central Europe. In J. Brown, N. Mitchell \& M. Beresford (Eds.), The protected landscape approach: Linking nature, culture and community (pp. 131-146). Gland: IUCN.

La Rosa, D., Privitera, R., Martinico, F. \& La Greca P. (2013). Measures of safeguard and rehabilitation for landscape protection planning: A qualitative approach based on diversity indicators. J. Environ. Manag., 127(Suppl.), S73S83. DOI: 10.1016/j.jenvman.2012.12.033.

Lindner, M., Maroschek, M., Netherer, S., Kremer, A., Barbati, A., Garcia-Gonzalo, J., Seidl, R., Delzon, S., Corona, P., Kolstrom, M., Lexer, M.J. \& Marchetti M. (2010). Climate change impacts, adaptive capacity, and vulnerability of European forest ecosystems. For. Ecol. Manag., 259, 698-709. DOI: 10.1016/j.foreco.2009.09.023.

Löffler, R. \& Steinicke E. (2006). Counterurbanization and its socioeconomic effects in High Mountain Areas of the Sierra Nevada (California/Nevada). Mt. Res. Dev., 26(1), 64-71. DOI: 10.1659/0276-4741(2006)026[0064:CAISE I] 2.0.CO;2 .

Łowicki, D. (2008). Land use changes in Poland during transformation: case study of Wielkopolska Region. Landsc. Urban Plann., 87, 279-288. DOI: 10.1016/j.landurbplan.2008.06.010. 
MacArthur, R.H. \& Wilson E.O. (2001). The theory of Island biogeography. Princeton, New York: Princeton University Press.

Mallarach, J.M. (Ed.) (2008). Protected landscapes and cultural and spiritual values. Vol. 2. Values of protected landscapes and seascapes. Heidelberg: Kasparek Verlag.

Mancinelli, R., Campiglia, E., Caporali, F. \& Di Felice V. (2010). Habitat patch diversity evaluation for sustainability: a case study of a rural area in central Italy. Italian Journal of Agronomy, 5(4), 341-352. DOI: 10.4081/ija.2010.341.

Mcdonald, R.I., Kareiva, P. \& Forman R.T.T. (2008). The implications of current and future urbanization for global protected areas and biodiversity conservation. Biol. Conserv., 141, 1695-1703. DOI: 10.1016/j.biocon.2008.04.025.

Mcdonald, R.I., Forman, R.T.T., Kareiva, P., Neugarten, R., Salzer, D. \& Fisher J. (2009). Urban effects, distance, and protected areas in an urbanizing world. Landsc. Urban Plann., 93, 63-75. DOI: 10.1016/j.landurbplan.2009.06.002.

Mizgajski, A., Bródka, S., Fagiewicz, K., Kijowska, J., Łowicki, D., Markuszewska, I. \& Poniży L. (2010). Natural conditions as a premise for the development of the Poznań urbanised area. The Problems of Landscape Ecology, 28, 91-100.

Navarro-Cerrillo, R.M., Guzmán-Álvarez, J.R, Clavero-Rumbao, I. \& Ceaceros C. (2013). A spatial pattern analysis of landscape changes between 1956-1999 of Pinus halepensis Miller plantations in Montes de Malaga State Park (Andalusia, Spain). Applied Ecology and Environmental Research, 11(2), 293-311.

Phillips, A. (2001). Protected landscape - a protected areas model for the $21^{\text {st }}$ century. In Landscape conservation (pp. 50-51). Vermont: Conservation Study Institute.

Phillips, A. \& Partington R. (2005). Protected landscapes in the United Kingdom. In J. Brown, N. Mitchell \& M. Beresford (Eds.), The protected landscape approach: Linking nature, culture and community (pp. 118-130). Gland: IUCN.

Raszka, B. (2002). The introduction of spatial order in Puszcza Zielonka Landscape Park and Powidzki Landscape Park (in Polish). In K. Zimniewicz (Ed.), Management of a landscape park in the conditions of sustainable development. Poznań: Wydawnictwo Akademii Ekonomicznej.

Regulation No. 4/05 of the Wielkopolska Province Governor of 18 April 2005 on the Protection of the Puszcza Zielonka Landscape Park (2005). Official Journal of the Wielkopolska Voivodeship 49, item. 1527.

Resolution No. XLVI/690/10 of the Regional Parliament of the Wielkopolska Province of 26 April 2010 on adopting amendment in the Spatial Development Plan of the Wielkopolska Province (2010), Poznań (in Polish).

Salvati, L., Sateriano, A. \& Zitti M. (2013). Long-term land cover changes and climate variations - A country-scale approach for a new policy target. Land Use Policy, 30(1), 401-407. DOI: 10.1016/j.landusepol.2012.04.012.

Skokanová, H. \& Eremiášová R. (2013). Landscape functionality in protected and unprotected areas: case studies from the Czech Republic. Ecological Informatics, 14, 71-74. DOI: 10.1016/j.ecoinf.2012.11.007.

Solon, J. (2009). Spatial context of urbanization: Landscape pattern and changes between 1950 and 1990 in the Warsaw metropolitan area, Poland. Landsc. Urban Plann., 93(3-4), 250-261. not in the text DOI: 10.1016/j.landurbplan.2009.07.012.

Sołowiej, D. (1992). Fundamentals of environmental assessment methodology (in Polish). Poznań: Wydawnictwo Naukowe UAM.

Southworth, J., Nagendra, H. \& Munroe D.K. (2006). Introduction to the special issue: Are parks working? Exploring human-environment tradeoffs in protected area conservation. Applied Geography, 26, 87-95. DOI: 10.1016/j. apgeog.2005.11.001.

Spatial Development Plan of the Wielkopolska Province (2010). Wielkopolskie Biuro Planowania Przestrzennego, Poznań (in Polish).

Stockdale, A. \& Barker A. (2009). Sustainability and the multifunctional landscape: An assessment of approaches to planning and management in the Cairngorms National Park. Land Use Policy, 26, 479-492. DOI: 10.1016/j.landusepol.2008.07.001.

Švajda, J. (2011). Evaluation of integrated protected area management in Slovak national parks. Ekológia (Bratislava), 30(1), 141-155. DOI: 10.4149/ekol_2011_01_141.

Verburg, P.H., Overmars, K.P., Huigen, M.G.A., de Groot, W.T. \& Veldkamp A. (2006). Analysis of the effects of land use change on protected areas in the Philippines. Applied Geography, 26, 153-173. DOI: 10.1016/j.apgeog.2005.11.005.

Wolski, P., Kistowski, M., Cieszewska, A. \& Kaliszuk E. (2000). Landscape structure and spatial planning - relations and conflicts. 3rd International Workshop on Sustainable Land Use Planning. Wageningen.

Wyman, M.S. \& Stein T.V. (2010). Modeling social and land-use/land-cover change data to assess drivers of smallholder deforestation in Belize. Applied Geography, 30(3), 329-342. DOI: 10.1016/j.apgeog.2009.10.001.

Ziarnek, M. (2007). Human impact on plant communities in urban area assessed with hemeroby grades. Pol. J. Ecol., 55(1), 161-167. 